\title{
Magnetostratigraphy of the Middle Jurassic Sediments from Kachchh Basin, Western India
}

\author{
Venkateshwarlu Mamilla1*, Bindhyachal Pandey², Deo Brat Pathak², Papanna Guguloth1, \\ Jai Krishna ${ }^{2}$ \\ ${ }^{1}$ Paleomagnetism Division, CSIR-National Geophysical Research Institute, Hyderabad, India \\ ${ }^{2}$ Department of Geology, Banaras Hindu University, Varanasi, India \\ Email: "mamila_v@rediffmail.com
}

Received 22 January 2016; accepted 19 March 2016; published 22 March 2016

Copyright (C) 2016 by authors and Scientific Research Publishing Inc.

This work is licensed under the Creative Commons Attribution International License (CC BY).

http://creativecommons.org/licenses/by/4.0/

(c) (i) Open Access

\section{Abstract}

The palaeoposition of India after its breakup from Gondwana and its subsequent northward journey during the Mesozoic poses many tectonic riddles. A magnetostratigraphy pattern has been constructed for the Ammonoid rich Middle Jurassic Bathonian succession of Jumara Dome, Kachchh, western India. We present the first magnetostratigraphic results from the Ammonoid bearing exposed Bathonian sediments in Kachchh. The Jumara Dome comprised of mixed carbonatesiliciclastic succession is represented by the Jhurio and Patcham formations and siliciclasticdominating Chari Formation in the Kachchh Mainland. The Jumara Dome sediments were deposited during sea-level fluctuating, and were interrupted by storms in the shallow marine environment. This study is based on collection of 60 oriented samples from 13 successive levels. Both thermal and AF demagnetization investigations were carried out to isolate the Characteristic Remanent Magnetization (ChRM) directions. Palaeolatitudes were computed using the ChRM directions. Magnetostratigraphic column is prepared and correlated with Geological Time Scale (GTS) of [1] [2], and this column readily matched with GTS at M41 to below and exhibits the dominance of normal polarity in Jumara.

\section{Keywords}

Magnetostratigraphy, Jurassic, Kachchh, India

\section{Introduction}

Several models based on geological and geophysical evidences for the tectonic evolution of the Indian plate *Corresponding author.

How to cite this paper: Mamilla, V., Pandey, B., Pathak, D.B., Guguloth, P. and Krishna, J. (2016) Magnetostratigraphy of the Middle Jurassic Sediments from Kachchh Basin, Western India. International Journal of Geosciences, 7, 301-310. 
from its Pangean origin to the present day was proposed by [3]. The evolution of the Indian plate is least understood among all the Gondwana landmasses. The first stage of rifting of Pangea took place in middle Jurassic during this time India was still a part of Gondwana. During the first phase of continental rifting Gondwana broke apart in to two equal parts, western Gondwana composed of Africa and south America and eastern Gondwana composed of India, East Antarctica, Madagascar, Australia, the Seychelles, and other microcontinental blocks, separated from Africa in the Mid-Jurassic [4] [5].

The Kachchh basin formed due to rifting and counter-clockwise rotation of the Indian plate in the Late Triassic/Early Jurassic [6]. The basin is bordered by the subsurface Nagarparkar Massif in the north, RadhanpurBarmer Arch in the east and Kathiawar uplift to the south [7]. In this pericratonic rift basin [8]-[10], Mesozoic sediments ranging in age from Bajocian to Albian lay unconformably on the Precambrian basement [11]. The Mesozoic sediments are exposed in the Kachchh Mainland, Patcham, Khadir, Bela, Wagad and Chorad Islands in the Great Runn of Kachchh. These sediments are dominantly represented by Siliciclastics. Magnetostratigraphic studies represent an important tool for correlation purposes since they deal with globally synchronous events such as inversions of the earth magnetic field. They set up important time constraints for biostratigraphic studies. As marine magnetic anomalies are recorded in the present-day oceanic floors, the magnetic polarity time scale is well defined from Jurassic to Recent.

The Middle Jurassic Ammonoid bearing Bathonian sedimentary successions are beautifully exposed in Kachchh Mainland and Island Belts of the Kachchh basin (Figure 1). The Bathonian sediments belong to the Patcham Formation, the oldest lithostratigraphic unit of lithostratigraphic framework of [12] [13] (Table 1). The fossiliferous Bathonian section is found the best developed at Jumara in the Kachchh Mainland (Figure 1). However, these sediments present their beautiful outcrops also in Patcham Island (Sadhara Dome, Kala Dongar and Gora Dongar range) and other localities of the Kachchh Mainland (Jhura, Nara and Habo Domes). Recent development towards the investigation of exposed Bathonian sediments at Jumara, Kachchh Mainland envisages the formulation of high resolution ammonoid biochronology [14]. The sedimentary succession at Jumara has been litho- and bio-stratigraphically resolved and is expected to be potential exposure for integrated litho-biomagneto-stratigraphic studies during Bathonian interval (167.7 Ma to 164.4 Ma, GTS 2008) in India.

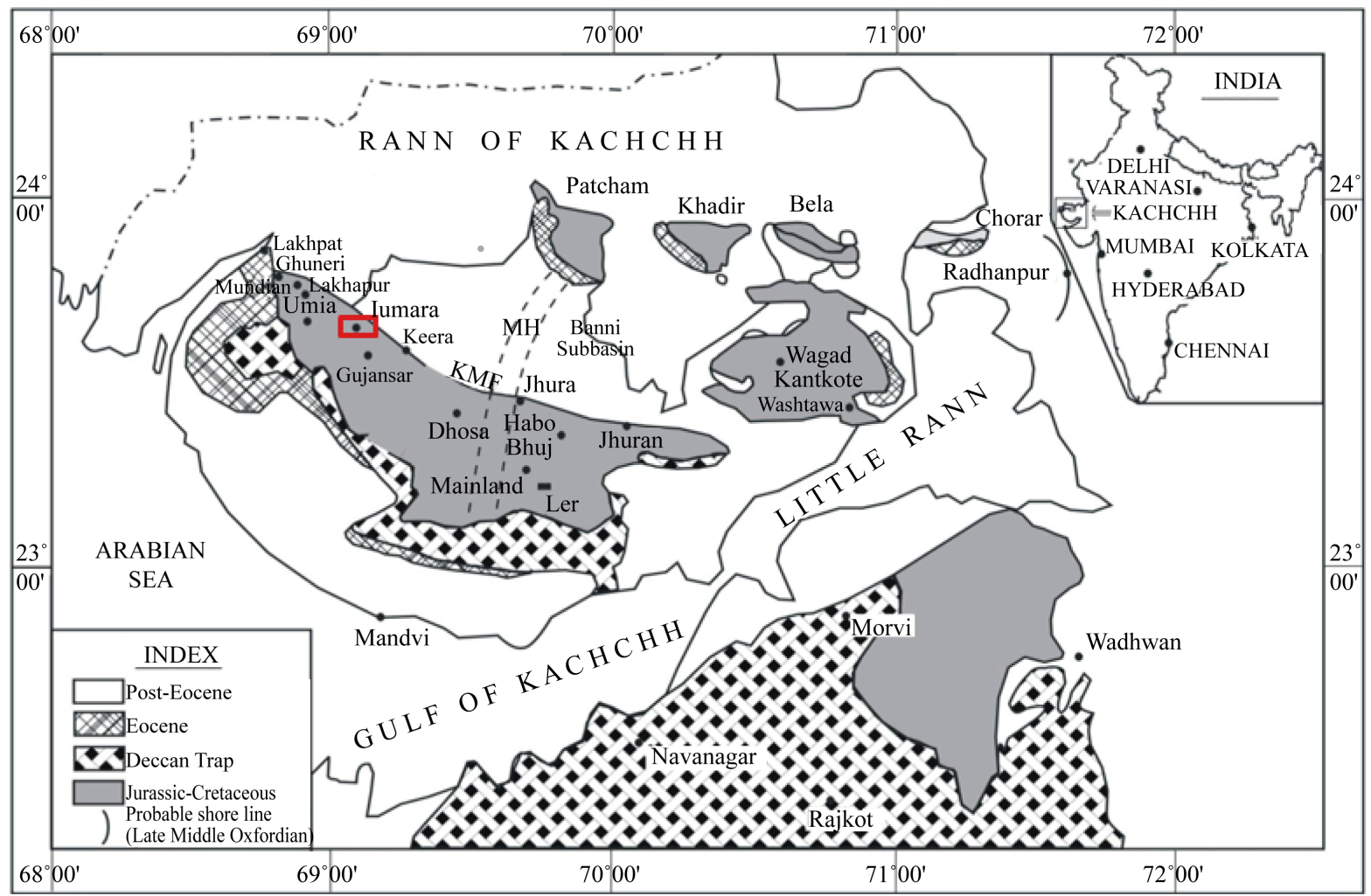

Figure 1. Geological map of the Kachchh, western Gujarat, India showing the study area in red rectangular shape [15]. 
Table 1. Lithostratigraphic framework of Mesozoic sedimentary succession of Kachchh, western India and their ages (after Pandey et al. 2012).

\begin{tabular}{cc}
\hline FORMATION & AGE \\
\hline Umia & Late Tithonian - Aptian/?Early Albian \\
Katrol & Late Oxfordian - Early Tithonian \\
Chari & Callovian - Middle Oxfordian \\
Patcham & Bajocian or older - Bathonian \\
\hline
\end{tabular}

The aim of this work is to correlate different biozonal scales in different regional settings and to contribute to the development of a standard Jurassic magnetic polarity scale in the Tethyan realm. The present study in the Jumara section is the first ever attempt to develop a magnetostratigraphic framework in the Bathonian of Kachchh, its correlation with standard magnetostratigraphic scale of [2] and also its integration with ammonoid zones of Kachchh [14] and standard Tethyan scheme [16]. The Bathonian magnetic polarity stratigraphy is very ambiguous in other parts of the globe.

\section{Geological Setting and Sampling}

\section{Lithostratigraphic Remarks}

The exposed Bathonian sediments at Jumara is $\sim 51 \mathrm{~m}$ thick and correspond to the part of the Patcham Formation. The base is not exposed while overlying Chari Formation bears conformable contact with these sediments (Table 1). The Bathonian outcrop in the study area is predominantly composed of relatively fine textured limestone and shale/silt/marl among which most of the limestone beds yielding ammonoids and other invertebrate fauna. The lower part of the succession ( $18 \mathrm{~m}$ thick) is mainly consisted of alternating beds/bands of yellowish white shale/marl and yellowish gray to earthy limestone. This part of the succession is highly rich in corals besides subordinate presence of other invertebrates. The overlying fossiliferous unit ( 33 m thick) is characterized by having alternating succession of grayish white/whitish marly limestone and earthy shale/silt.

The Paleomagnetic sampling was done by collecting 60 oriented block samples from 13 sites. The samples were prepared in to standard cylindrical specimens of size $2.5 \mathrm{~cm}$ diameter and $2.2 \mathrm{~cm}$ height. About $450 \mathrm{spe}-$ cimens have been obtained from 60 samples.

\section{Methodology}

The natural remanent magnetization (NRM) of all the specimens was measured on a JR-6 Spinner magnetometer (Brno, Czechoslovakia) in the paleomagnetic laboratory of the CSIR-National Geophysical Research Institute, India. Alternating field (AF) cleaning was systematically adopted using Molspin AF demagnetizer (Magnetic Measurements, UK). 51 specimens were demagnetized using 17 demagnetization steps per sample, from $5 \mathrm{mT}$ up to $150 \mathrm{mT}$ maximum AF field. AF treatment could remove up to $20 \%-80 \%$ of the natural remanence. Therefore, a batch of 59 specimens was also thermally demagnetized in 19 steps from $70^{\circ} \mathrm{C}$ up to $680^{\circ} \mathrm{C}$ using a thermal demagnetizer (Model MMTD-80, Magnetic Measurements, UK). Demagnetization data were plotted on both orthogonal demagnetization diagrams [17] and on equal-area projections and the magnetization components were isolated using principal component analysis [18]. The statistics of the paleomagnetic data obtained was conducted using [19] statistics analysis. The virtual geomagnetic pole (VGP) latitudes of the characteristic remanent magnetization components (ChRMs) from each sample with respect to the Earth's rotation axis were evaluated. The isothermal remanent magnetization (IRM) studies on 5 representative samples were analyzed using Pulse Magnetizer (Model MMPM 10, Magnetic Measurements, UK).

\section{Discussion}

\subsection{Paleomagnetic Results}

The NRM has been measured using JR-6 spinner Magnetometer and the intensities rage between $3.88 \times 10^{-4}$ and $1.05 \times 10^{-5} \mathrm{~A} / \mathrm{M}$, displaying lower values in the samples collected from Jumara Section. In order to separate the 
secondary NRM components 51 specimens were subjected to AF demagnetization. Figure 2 shows the orthogonal projections where the vector behavior during AF demagnetization is deciphered. In most of the samples, a ChRM could be isolated in $25-70 \mathrm{mT}$ were field intervals, after the elimination of a viscous component (Figures 2(a)-2(c)). Another set of 59 specimens subjected to Thermal Demagnetization. Figure 3 shows the orthogonal projections where the vector behavior during Thermal demagnetization is deciphered. In most of the studied samples, a low temperature magnetization is unblocked below $300^{\circ} \mathrm{C}-400^{\circ} \mathrm{C}$ after removal of a viscous component at $150^{\circ} \mathrm{C}$ (Figures 3(a)-3(c)). This low temperature component is parallel to the present-day geomagnetic field in in-situ coordinates and will not be considered further. A stable component with high unblocking temperature component was isolated above $300^{\circ} \mathrm{C}$ and $580^{\circ} \mathrm{C}$, a ChRM can be identified in about $90 \%$ of the samples. Significant decay in the NRM intensity below $580^{\circ} \mathrm{C}$ indicates the predominant contribution of magnetite, in addition to hematite, in some of the samples.

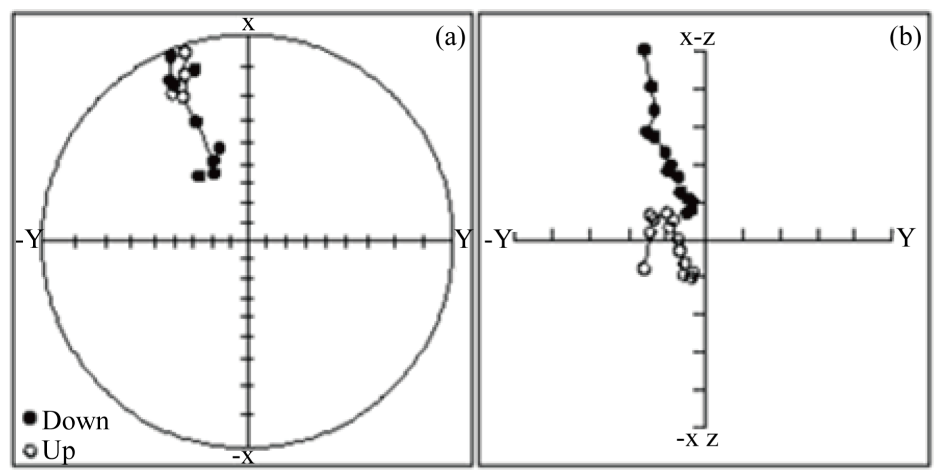

KJ $1.2 \mathrm{e}$

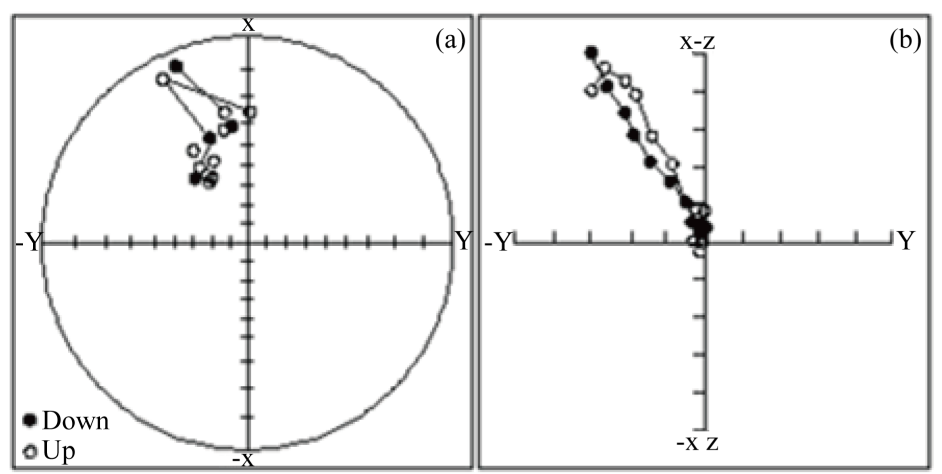

KJ $1.3 \mathrm{a} 1$

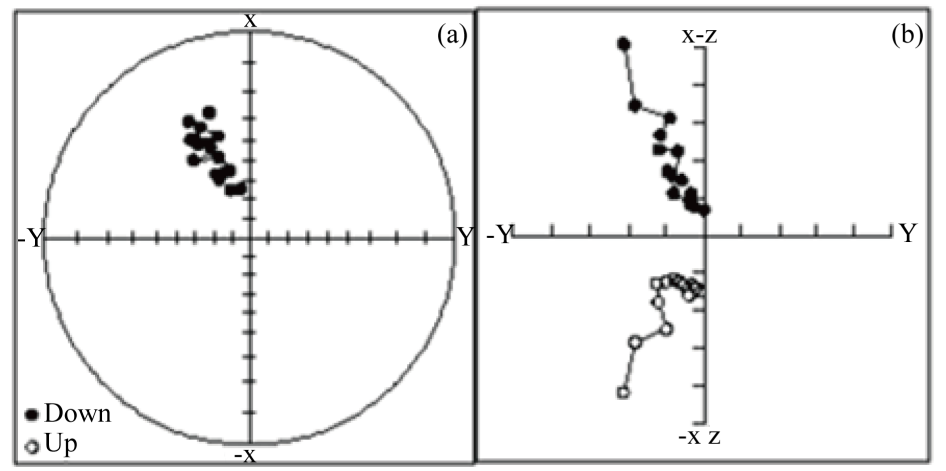

KJ 8.4cll
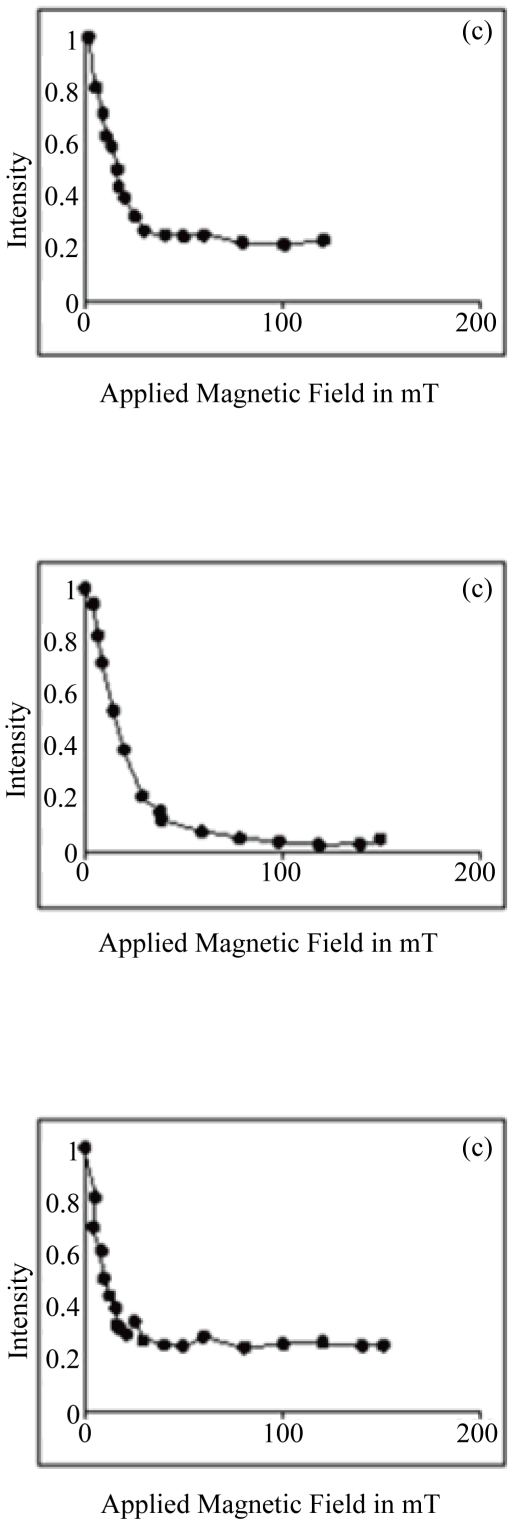

Figure 2. Examples of orthogonal vector diagrams during AF demagnetization. (a) Vector migration diagram; (b) orthogonal projection. Closed (open) symbols are projection onto the horizontal (vertical) plane; (c) intensity decay curves. 


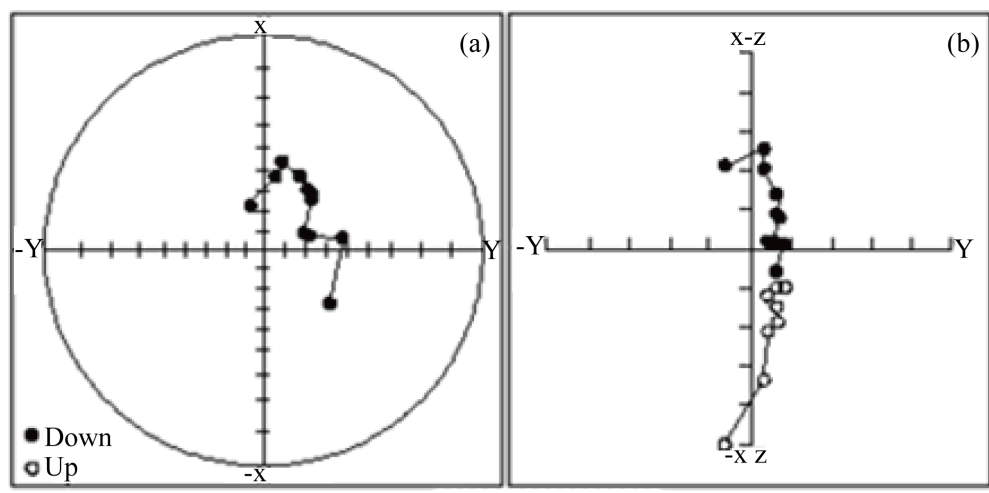

KJ 2.3bll

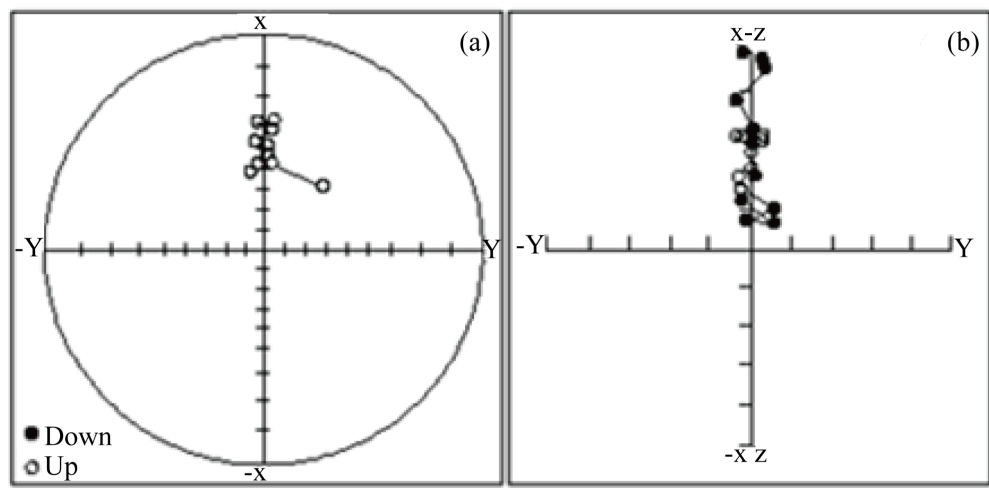

KJS 1.4al

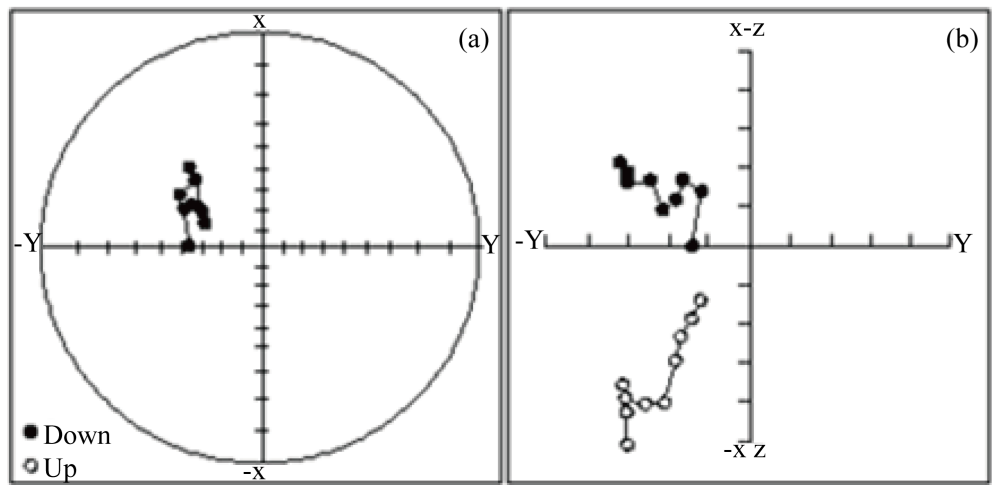

KJS $2.3 \mathrm{bl}$

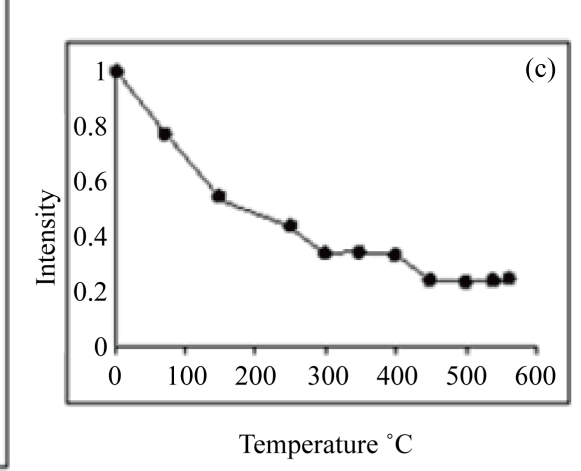

(b)
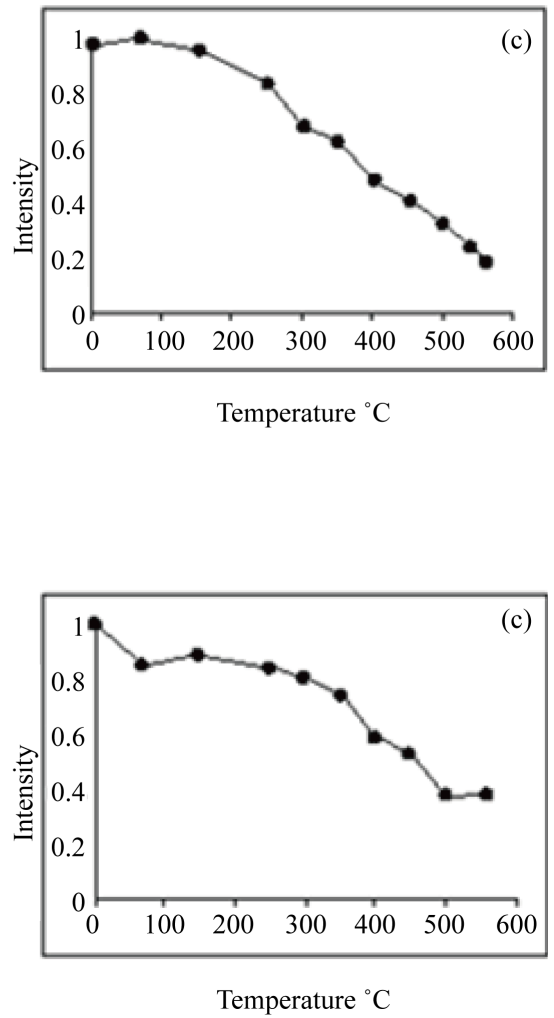

Figure 3. Examples of orthogonal vector diagrams during thermal demagnetization. (a) Vector migration diagram; (b) orthogonal projection. Closed (open) symbols are projection onto the horizontal (vertical) plane; (c) intensity decay curves.

It is clear that thermal demagnetization is much more efficient than AF for most of the specimens. This suggests that the magnetic mineralogy of the studied Jumara limestones is dominated by magnetite but a small amount of hematite is also present. Such magnetic mineralogy is rather constant, and similar for samples displaying a normal polarity. The characteristic magnetization vector has been calculated by means of linear regression analysis [18]. The majority of the samples were clearly characterized by a two-component magnetization, examples of which are given in Figure 2 and Figure 3. The stable component, referred to as the characteristic remanent magnetization component (ChRM), shows single polarity in northerly declination with positive/negative inclination (Figure 4). Figure 5 show the isothermal remanent magnetization curves indicating that the shale samples having hematite as the remanent carrier. Table 2 gives the Paleomagnetic results from 


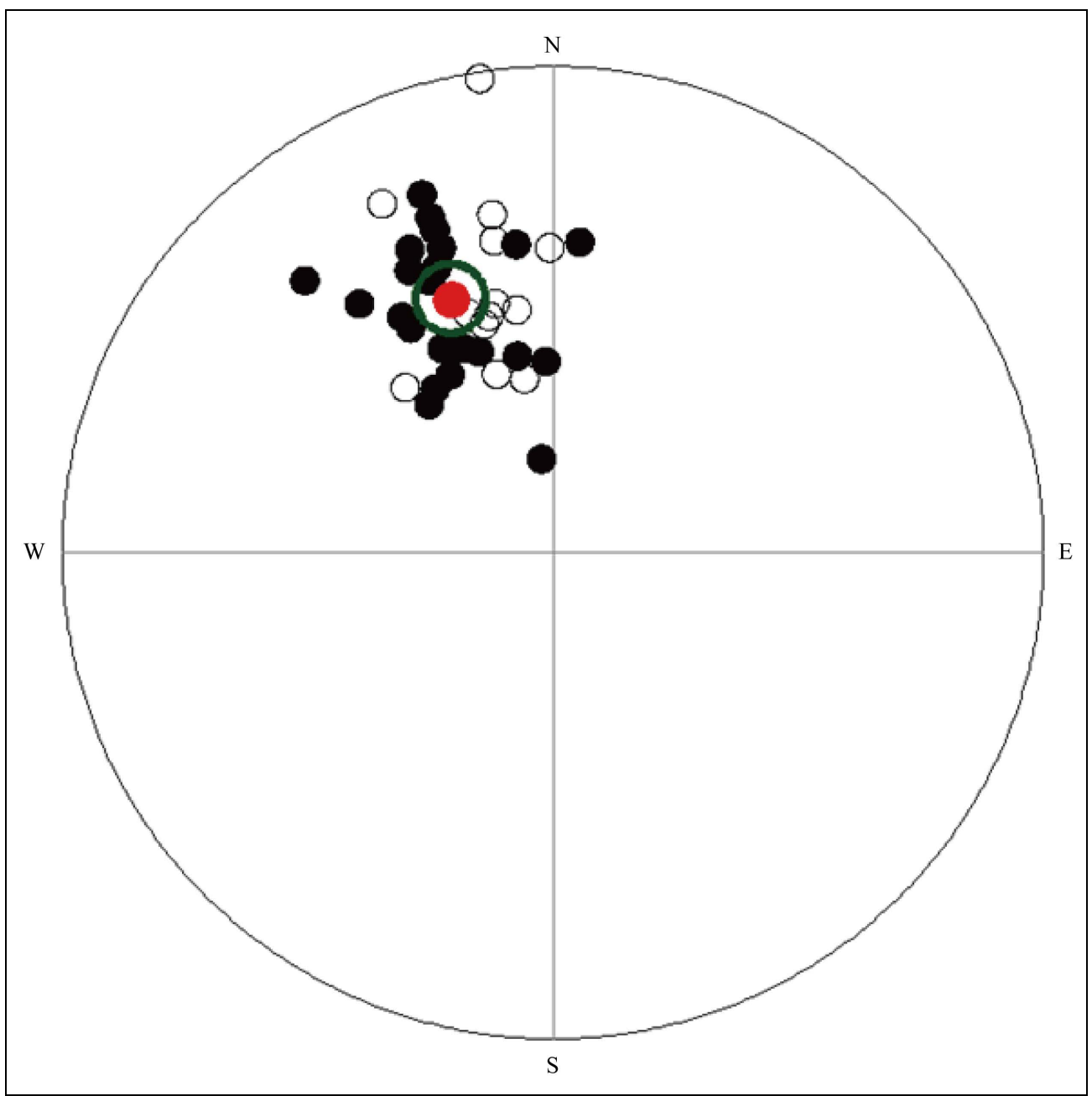

Figure 4. Mean ChRM directions along with grand mean for Jumara section, Kachchh basin.

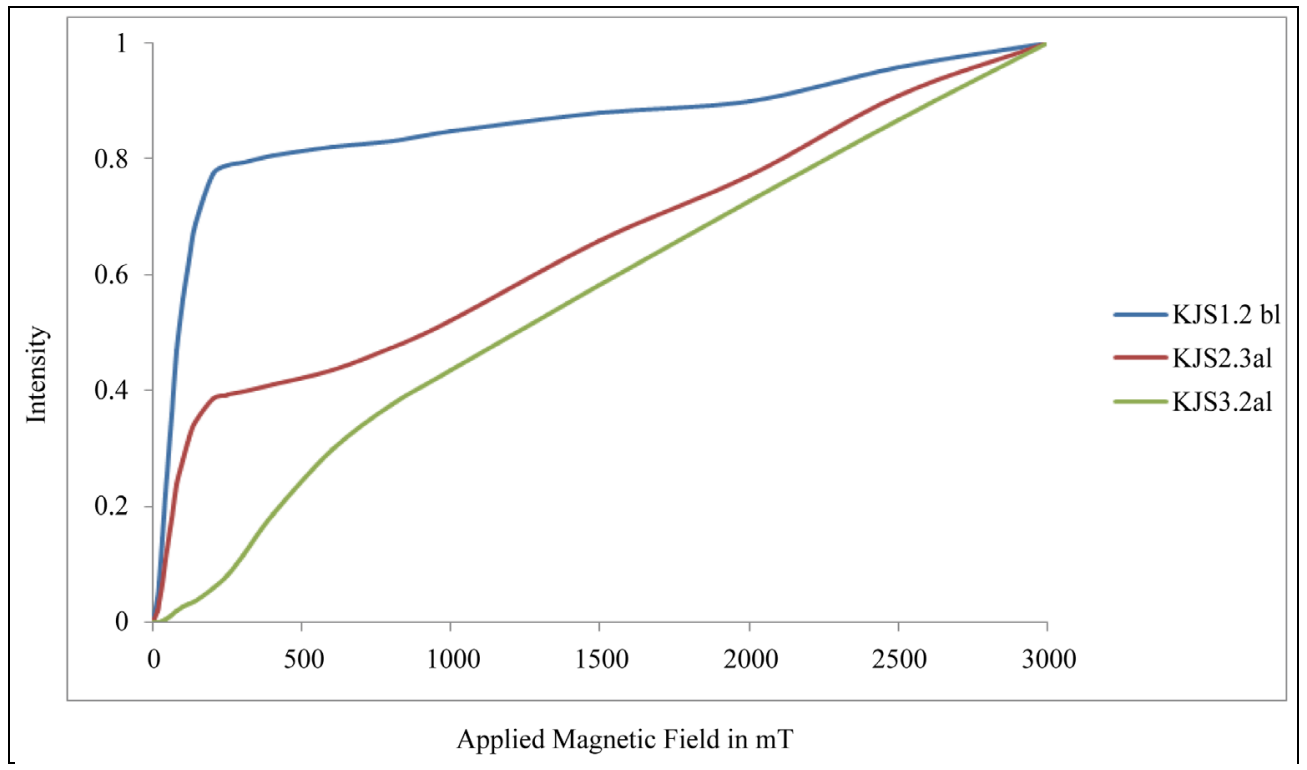

Figure 5. IRM curves for Jumara section samples, Kachchh Basin. 
Table 2. Paleomagnetic results from the Jumara section, Kachchh basin, western Gujarat, India. Sp. No.: Sample/Specimen number; Dm: mean Declination; Im: mean Inclination; $\alpha_{95}$ : circle of confidence about $95 \%$ probability level; k: precision parameter; VGP: Virtual Geomagnetic Pole.

\begin{tabular}{|c|c|c|c|c|c|}
\hline Sp. No. & Dm & Im & $\alpha_{95}$ & k & VGP \\
\hline KJ1.1 & 338 & -32 & 14.20 & 42.85 & 64.14 \\
\hline KJ1.2 & 344 & -38 & 19.92 & 22.24 & 42.57 \\
\hline KJ1.3 & 339 & -29 & 6.35 & 146.34 & 45.92 \\
\hline KJ2.1 & 290 & 46 & 41.18 & 10.02 & 45.92 \\
\hline KJ2.2 & 352 & 68 & 10.61 & 555.83 & 57.57 \\
\hline KJ2.3 & 358 & 47 & 19.58 & 22.99 & 78.92 \\
\hline KJ2.4 & 318 & 16 & 21.98 & 131.21 & 43.98 \\
\hline KJ3.1 & 329 & -36 & 99.72 & 8.63 & 37.03 \\
\hline KJ3.3 & 331 & -42 & 20.77 & 36.27 & 34.44 \\
\hline KJ4.2 & 353 & 25 & 12.19 & 57.78 & 56.02 \\
\hline KJ5.1 & 334 & -13 & 28.28 & 19.36 & 50.67 \\
\hline KJ5.2 & 340 & 19 & 21.40 & 34.25 & 66.25 \\
\hline KJ5.3 & 327 & 30 & 12.98 & 35.72 & 57.78 \\
\hline KJ5.4 & 335 & 22 & 16.65 & 22.08 & 60.64 \\
\hline KJ5.5 & 340 & 22 & 19.80 & 15.82 & 64.89 \\
\hline KJ6.1 & 335 & 41 & 92.86 & 9.55 & 54.45 \\
\hline KJ6.2 & 318 & -42 & 16.55 & 31.77 & 38.22 \\
\hline KJ6.3 & 340 & -35 & 11.61 & 113.73 & 52.67 \\
\hline KJ6.4 & 288 & -33 & 38.61 & 6.63 & 16.40 \\
\hline KJ6.5 & 339 & -32 & 25.97 & 23.60 & 45.29 \\
\hline KJ7.1 & 340 & 43 & 25.25 & 24.90 & 76.21 \\
\hline KJ7.3 & 331 & 31 & 42.30 & 9.56 & 71.88 \\
\hline KJ7.4 & 325 & 45 & 18.22 & 26.39 & 58.07 \\
\hline KJ7.5 & 338 & 26 & 16.53 & 31.86 & 65.12 \\
\hline KJ8.1 & 350 & -20 & 15.26 & 37.20 & 52.09 \\
\hline KJ8.3 & 322 & 25 & 22.15 & 18.18 & 54.16 \\
\hline KJ8.4 & 332 & 40 & 30.07 & 17.87 & 59.62 \\
\hline KJ8.5 & 351 & -1 & 107.25 & 7.83 & 64.16 \\
\hline KJ9.1 & 350 & -24 & 27.73 & 11.95 & 61.74 \\
\hline KJ9.2 & 340 & 15 & 25.64 & 13.81 & 65.53 \\
\hline KJ9.3 & 333 & 25 & 30.60 & 17.29 & 61.99 \\
\hline KJ9.4 & 336 & 28 & 49.84 & 7.19 & 63.83 \\
\hline KJ9.5 & 327 & 34 & 61.75 & 5.16 & 60.37 \\
\hline KJ10.1 & 346 & -36 & 49.28 & 7.33 & 63.18 \\
\hline KJ10.2 & 328 & 45 & 26.54 & 12.95 & - \\
\hline KJ10.3 & 5 & 25 & 135.48 & 1.97 & - \\
\hline KJ10.4 & 330 & 35 & 52.43 & 6.6 & - \\
\hline KJS1.1 & 351 & -37 & 5.19 & 314.24 & 47.33 \\
\hline KJS1.2 & 359 & -26 & 10.74 & 74.21 & 73.93 \\
\hline KJS1.4 & 351 & -51 & 13.86 & 80.16 & - \\
\hline KJS2.1 & 345 & -37 & 76.88 & 12.79 & - \\
\hline KJS2.2 & 343 & -48 & 22.74 & 122.71 & - \\
\hline KJS2.3 & 321 & 47 & 55.24 & 22.60 & - \\
\hline KJS3.2 & 351 & 46 & 34.76 & 53.73 & 87.55 \\
\hline Grand Mean & 337 & 6 & 11.01 & 4.81 & - \\
\hline
\end{tabular}


the Jumara section of Kachchh basin. Petrography and geochemistry studies are done on the sediments of Jumara dome [20] emphasized that the sandstones/shales were deposited on a passive margin of the stable intracratonic basin. The results of paleocurrent direction on the Jurassic sandstones/shales of the Kachchh Basin suggests that sand detritus was mostly derived from the Aravalli range situated to the northeast, east and southeast of the Kachchh basin and from the Nagar parker massif situated to north and northwest of the Kachchh basin.

\subsection{Magnetostratigraphy}

A magnetostratigraphic sequence has been established by plotting the Virtual Geomagnetic Pole (VGP) of the ChRM component of each sample as a function of its stratigraphic position. Figure 6 is the plot of the VGP Latitudes against the Lithocolumn. A clear magnetic zonation of the sedimentary sequence at Jumara is defined. Interestingly the Jumara section has not recorded any reverse polarity. Entire section has recorded the normal

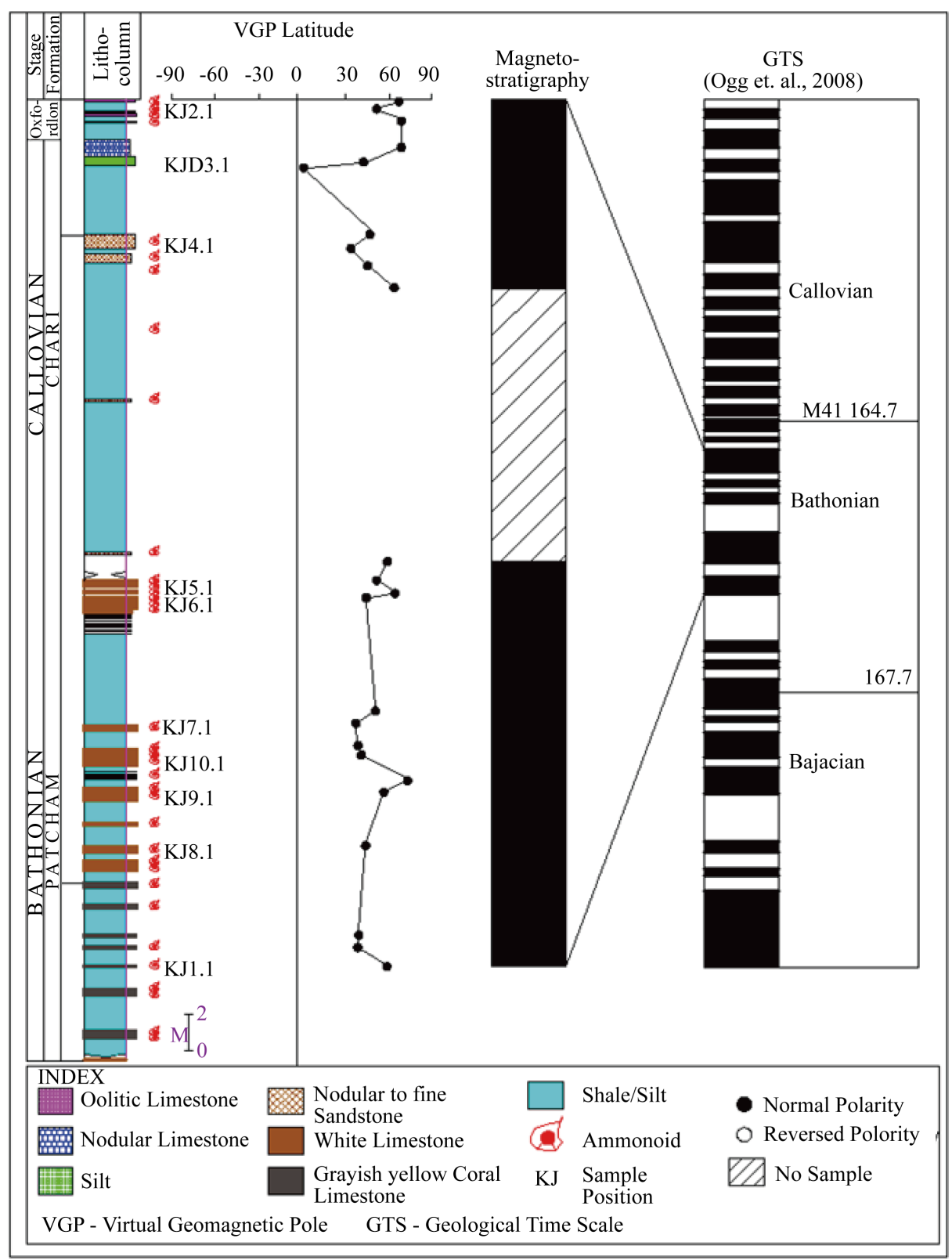

Figure 6. Plot of Lithostratigraphy against the sampling sites. Magnetostratigraphy of the Jumara Section and its correlation with standard GTS of [1] [2]. 
polarity, there are some indications at lower part of the section where hard shales were sampled have shown southern hemisphere declinations with positive inclination (2 - 3 specimens), however we have not considered these results in the statistics. The Magnetostratigraphy column is correlated with the standard Geological Time Scale (GTS) of Ogg et. al., 2008. The Bathonian period in GTS range from 167.7 - 164.7 which is having 2 - 3 major reversals where the Jumara section has not recorded this polarity. Moreover there is no certain major zones exist in GTS below M41 and it is difficult to correlate this section with standard GTS. However, with the available literature on Paleontology and fossil content of this section the MPS can be placed at middle Bathonian in GTS at M41 or above/below.

\section{Conclusion}

This paper presents the first magnetostratigraphic dating of the fossil-bearing continental sediments of the Jumara section, Kachchh basin, western India. From the magnetic mineralogy study it is inferred that the primary remanent magnetization resides in magnetite as well as hematite. The erected magnetic polarity stratigraphy column indicates that the Jumara section correlates well with standard GTS of [1] [2]. Based on this correlation the MPS can be placed at middle Bathonian to lower Callovian in GTS at M41 or below/above.

\section{Acknowledgements}

Authors (M.V) thank the Director, CSIR-National Geophysical Research Institute for the permission to publish this work. Authors also thank the Department of Science and Technology, Government of India for the financial support (SR/S4/ES-261/2007).

\section{References}

[1] Gradstein, F.M., Ogg, J.G., Smith, A.G., Agterberg, F.P., Bleeker, W., Cooper, R.A.,Davydov, V., Gibbard, P., Hinnov, L.A., House, M.R., Lourens, L., Luterbacher, H-P., McArthur, J., Melchin, M.J., Robb, L.J., Sadler, P.M., Shergold, J., Villeneuve, M., Wardlaw, B.R., Ali, J., Brinkhuis, H., Hilgen, F.J., Hooker, J., Howarth, R.J., Knoll, A.H., Laskar, J., Monechi, S., Powell, J., Plumb, K.A., Raffi, I., Röhl, U., Sanfilippo, A., Schmitz, B., Shackleton, N.J., Shields, G.A., Strauss, H., Van Dam, J., Veizer, J., Van Kolfschoten, Th. and Wilson, D. (2004) Geologic Time Scale 2004. Cambridge University Press, Cambridge, 589 p. http://dx.doi.org/10.4095/215638

[2] Ogg, J.G., Ogg, G. and Gradstein, F.M. (2008) The Concise Geologic Time scale. Cambridge University Press, Cambridge, $150 \mathrm{p}$.

[3] Chatterjee, S. and Scotese, C.R. (1999) The Breakup of Gondwana and the Evolution and Biogeography of the Indian plate. PINSA, 64, 397-425.

[4] Eagles, G. and Konig, M. (2008), A Model of plate Kinematics in Gondwana Breakup. Geophysical Journal International, 173, 703-717. http://dx.doi.org/10.1111/j.1365-246X.2008.03753.X

[5] Royer, J.Y. and Coffin, M.F. (1992) Jurassic to Eocene Plate Tectonic Reconstructions in the Kerguelen Plateau Region. In: Schlich, R. and Wise, S.W., et al., Eds., Proceedings of the Ocean Drilling Program, Scientific Results, Volume 120, Ocean Drilling Program, Texas A\&M University, College Station, 917-930,

[6] Biswas, S.K. (1987) Regional Tectonic Framework, Structure and Evolution of the Western Marginal Basins of India. Tectonophysics, 135, 307-327. http://dx.doi.org/10.1016/0040-1951(87)90115-6

[7] Biswas, S.K. (1982) Rift Basins in Western Margin of India and Their Hydrocarbon Prospects with Special Reference Kutch Basin. Bulletin of the American Association of Petroleum Geologists, 65, 1497-1513.

[8] Datta, A.K. (1983) Geological Evolution and Hydrocarban Prospects of Rajasthan Basin. In: Bhandari, L.L., Venkatchala, B.S., Kumar, R., Nanjudaswamy, S., Garg, P. and Srivastava, D.C., Eds., Petroliferous Basins of India, Petrolum Asia Journal, 4, 93-100.

[9] Biswas, S.K., Bhasin, A.L. and Ram, J. (1993) Classification of Indian Sedimentary Basins in the Framework of Plate Tectonics. Proceedings of the Second Seminar in Petroliferous Basins of India, 1, 1-46.

[10] Jaitley, A.K. and Singh, C.S.P. (1983) Discovery of Late Bajocian Leptosphinctes BUCKMAN (Jurassic Ammonitina) from Kachchh, Western India. Neues Jahrbuch fur Geologie und Palaontologie Monatshefe, 2, 91-96.

[11] Bardan, S. and Datta, K. (1987) Biostratigraphy of Jurassic Chari Formation: A Study in Keera Dome. Kutch, Gujarat. Journal Geological Society of India, 30, 121-131.

[12] Waagen, W. (1871) Abstract of Results of Examination of the Ammonite Fauna of Kutch with Remarks on Their Distribution among the Beds and Probable Age. Record of the Geological Survey of India, 4, 89-101. 
[13] Waagen, W. (1873-75) Jurassic Fauna of Katch, Cephallopoda. Memoir Paleontologia Indica, Geological Survey of India, 9, 1-247.

[14] Pandey, B., Pathak, D.B., Jaitley, A.K., Krishna, J. and Venkateshwarlu, M. (2012) Record of Tethyan Gastropod Genus Astrohelix Szabó, 1984 from Late Bajocian (Middle Jurassic) of Kachchh, Western India. Indian Journal of Geosciences, 66, 65-68.

[15] Wynne, A.B. (1872) Memoir on the Geology of Kutch to Accompany the Map Compiled by A.B. Wynne and F. Fidden during the Season of 1867-1868 and 1868-1869. Memoirs of the Geological Survey of India, 9, 1-293.

[16] Cariou, E. and Hantzpergue, P., Eds. (1997): Biostratigraphie du Jurassique ouest-européen et méditerranéen: zonations parallèles et distribution des invertébrés et microfossils. Bulletin du Centre Recherches Elf Exploration Production Mémoire, 17, 422 p.

[17] Zijderveld, J.D.A. (1967) AC Demagnetization of Rocks: Analysis of Results. In: Runcorn, S.K., Creer, K.M. and Collinson, D.W., Eds., Methods in Palaeomagnetism, Elsevier, Amsterdam, 254-286.

[18] Kirschvink, J.L. (1980) The Least Squares Line and Plane Analysis of Palaeomagnetic Data. Geophysical Journal International, 62, 699-718. http://dx.doi.org/10.1111/j.1365-246X.1980.tb02601.x

[19] Fisher, R. (1953) Dispersion on a Sphere. Proceedings of the Royal Society A, 217, 295-305. http://dx.doi.org/10.1098/rspa.1953.0064

[20] Ahmad, A.H.M., Noufal, K.N., Masroor Alam, M. and Khan, T. (2014) Petrography and Geochemistry of Jumara Dome Sediments, Kachchh Basin: Implications for Provenance, Tectonic Setting and Weathering Intensity. Chinese Journal of Geochemistry, 33, 9-23. http://dx.doi.org/10.1007/s11631-014-0656-4 